\title{
Teenage Pregnancy and the Quest for a Place for Pregnant Girls: A Study on the Rule of Pregnant Student Expulsion in Yogyakarta, Indonesia
}

\author{
Desintha Dwi Asriani \\ Ewha Womans University \\ (email: desintha.dda@gmail.com)
}

\begin{abstract}
This study attempts to reveal the problem that lies behind the discourse of teenage pregnancy in relation to the politics of place. It primarily derives from the tendency of a number of schools in Indonesia to expel pregnant students. The quest of a "place" simply refers to public spaces that are more contested for pregnant girls. However, the term place is not limited to its literal definition of physical location. Rather, it involves more complex dimensions such as gender dichotomy, body politics, and the politics of modernity. By examining interview data acquired from several school teachers and girls, this research will contextualize such case within the paradoxical relation between the conception of modernity in delivering the idea of progress and participation, and the extent to which the maternal body is mobilized within the discourse of gender dichotomy in public.
\end{abstract}

\section{Keywords:}

teenage pregnancy; pregnant students; teenage girls; gender-based discipline

\section{Introduction}

Despite the limitation of references available to elaborate on adolescent studies in Indonesia, feminism does not often discuss girls as a separated subject. While the term adolescent in Indonesia remains debatable whether it should be seen as an age-based category (Sarlito, 2011) or a contest of social changes (Handajani, 2008), feminism has yet to take the girls' phenomena under serious consideration (Ringrose \& Renold, 2016). This paper, by reflecting on the case of pregnant girls among secondary school students group, aims to provide alternative spaces in dealing with youth issues as well as gender studies in Indonesia. In addition, this study primarily seeks to question how has the rule of expelling pregnant students caused such a dislocation for the girls in public spaces.
According to several studies in developed countries, teenage pregnancy is frequently examined in light of education trajectory for the pupils and poverty issues (Caldas 1993, Oyorte and Pobi 2003, Adam, Taylor, and Pittman 1989). In the United States where the number of teenage pregnancy is the highest (Kearney \& Levine, 2012), although poverty had been considered as a prominent factor, several studies argue that the causes of teenage pregnancy should be scrutinized through more complex contexts. Caldas (1993) mentions that teenage pregnancy in the United States can be traced using various hypotheses such as reproductive ignorance, psychological issues, welfare, parental role, and social norms. This means that intertwining facts of human behaviors, biological conditions, and sociological aspects have significantly contributed to the rate of 
teenage pregnancy. On the other hand, Kelly (1996) tries to discover the social effects of being teen mothers by analyzing stigma stories among various groups in media accounts. Her study elucidates the dominant values of society about teen mothers that perpetuate the morality-based stereotype. This is an interesting research as it reveals that morality and social norms, in some ways, have greater potential of constructing the idea to abuse girls experiencing teenage pregnancy. It also puts forward a sensible argument, especially when the author concludes that rather than considering the case of teen mothers as a cycle of social problem, the stigma is not regarded as a better preventive action if teen mothers were necessarily seen as a social problem.

The study of teenage pregnancy in South Korea, similar to Indonesia, is not often discussed. Although South Korea may be categorized as a developed country, teenage pregnancy or pregnant student cases are a taboo to be widely exposed in public (Kim, 2014). In the Korea case, traditional perspectives have significantly influenced the creation of substantial boundaries for pregnant girls to be fully accepted as community members in the society (Kim, 2014). It may serve as an insightful reference to argue for the importance of framing teenage pregnancy as a critical issue. However, it does not provide sufficient explanations in resolving the problem of the girls as a public actor.

Indeed, such perspectives of structuralism provide clear explanation that unintended pregnancy among teenagers would disrupt normal conditions. It may lead to cases of female student drop outs, unsafe abortion, poverty, and domestic violence in early marriage lives. Nevertheless, the general regulation on pregnancy seems to be ahistorical. It lacks sufficient description to answer the questions of why and when does maternal life such as pregnancy is no longer regarded as something natural and should be categorized or regulated through certain punishments.
This paper is not opposed to the idea of diminishing the risks of teenage pregnancy. Nor does it dispute whether being a pregnant student is a violation or that of free choice. Even more so, it is to reveal the political discourse that lies behind the modern punishment when schools must expel pregnant students. I hope that this paper can specifically show how modernity positions girls' experiences and thus it may lead to a general outlook on the level of thinking we are applying to nurture today's younger generation.

\section{Theoretical Framework}

The theoretical background employed in this study firstly refers to Foucault's (1979) thoughts on the structures of power in modern institutions. It is the practices of discipline that expand the utility of the body within modern society (Kim, 2009). Since the human body becomes the most strategic field of power exercise, we need to be more aware of the terms applied to the body, such as masculinity or femininity, as it engages the strategy of discipline, docility, and panopticon. Therefore, in the case of premarital pregnancy, this theory is utilized to examine how regulations within modern institutions in Indonesia impose discipline over the girls' body.

Through Bartky's (1990) writing in Foucault, Femininity, and Modernization of Patriarchal Power, he argues that the mechanisms of discipline to increase the utility of the body has been magnified through the presence of modern society in institutions such as the army, schools, and hospitals. The institution's mechanism that regulates the desired behaviors of students, patients, and soldiers encapsulate the disciplinary practices that produce the "docile bodies" in which there are rich theoretical accounts of the ways to take hold of the body with a mass amount of historical detail. However, based on the gender framework, it is assumed that this theory has made overgeneralization, as if the bodily 
experiences of women and men are no different and as if all women and men deal with the same impacts in modern life (Bartky, 1990). Boys, even though they also contribute to unintended pregnancy, are usually free from threats of expulsion because the imprints of premarital sex always remains on the girls' body. Therefore, such implementation of sex education would, in fact, create boundaries for the girls. As pregnancy is attached to the women's body, people would initially perceive the girls as the source of the problem. In the context of pregnancy, if young girls were pregnant within the institution of marriage, people may regard them as being uneducated. However, if young girls were pregnant outside of marriage, they would be prone to be stigmatized as being promiscuous, a supporter of free sex, or a child coming from a broken family (Itriyati \& Asriani, 2014). Teenage pregnancy in schools is then assumed as being in contrast to modernity values. As Felsky (1995) said, pregnancy has always been considered as a maternal and traditional experience, it could not be a part of modernity values, which is considered to be very masculine. Accordingly, pregnancy and education are difficult to coexist, as well as the discordant relationship between a girl's role as mother and student.

Since bodily issues in the case of student pregnancy may create such a dislocation, it is also necessary to discuss the girl's body through the concept of politics of place. It could be one of the diverse embodiment (Sem, 2005) when pregnancy or the body is not a single entity. According to Nancy Scheper-Hughes \& Maragert M. Lock (1987), the divisions of mindful body may extend the discourse of the body to the agency or subjectivity levels. However, this paper does not attempt to completely reach that point. Embodiment here is described as a means to indicate how genderbased bodily experiences have influenced the maneuver of the body as a social symbol. Subsequently, pregnancy may lead the girls to a different meaning regarding places where they are free to act as a public actor within modern society.

\section{Methods}

The main data of this paper was collected from interviews conducted at the beginning of 2017 in Yogyakarta, Indonesia. Qualitative fieldwork was, specifically, conducted in this research by interviewing local girls, NGO activists, and teachers regarding their experiences in treating pregnant teenagers. Indepth conversations with girls who experienced teenage pregnancy were also purposely carried out in this study to delve deeper into their experiences in facing the existing obstacles. In addition, several teachers were interviewed to further explore the rules set up to expel pregnant students and the extent to which the issue of teenage pregnancy is manipulated to perpetuate certain discipline in modern institutions such as a school.

In the following discussion, the contested definition of teenage girl, which is a rare study in Indonesia, is initially described. This research contextualizes the idea of dealing with the girl through a paradigm shift of constructing girlhood in Indonesia which ranges from how parents in the Indonesian past understood the meaning of having a daughter to what being a girl in today's society means. I also present my arguments and analysis on the problems of the pregnancy discourse and the construction of being a girl, a maiden, and a woman in Indonesia. In the second part, I attempt to demonstrate the political interests behind the discourse of teenage pregnancy at the global level and in local narratives. It aims to examine how the issue of teenage pregnancy is maintained and mobilized by modernity and development agenda. The last part of the discussion section addresses the girls' experiences of being a pregnant teenager. It shows how the rule of expelling pregnant students really works in raising the 
pivotal question about the extent to which an unconditional place for these girls in public spaces is being advocated.

\section{Discussion}

\section{Girlhood in Indonesia}

The term teenager, in regards to the generation, is quite new in Indonesia (see Parker \& Nilan 2013). Historically, the term youths (pemuda) was more frequently used in Indonesia, particularly in relation to patriotism and nationalism. Youths are identified as the age group situated between children and adults, which is purposely created to build up human resources with the purpose of seizing independence during the colonial period. As commonly known, the history of war had always involved stories of soldiers, which was generally about the experiences of young people in defending the nation (Nagel, 1998). In short, in Indonesia, the term adolescent (remaja) has no gender meaning, while the notion of pemuda (youth) generally refers to young males. Accordingly, the space for discussing young girls as a subject is significantly limited.

Girls became a subject of study when an anthropology study revealed the practices of early marriage in Javanese family (Geertz, 1961). Early marriages were arranged by the parents soon after their daughter experienced her first menstruation cycle because if any negative outcome of premarital sex were brought upon their daughter/s, it would be a problem for the parents (Geertz 1964). It was considered to be truly embarrassing for parents when they found their daughter pregnant without a husband (Jones, 2001). Here, the construction of girlhood is closely associated with the demand to maintain a negative label. However, the coexisting ideology of modern education and feminism, has at a glance turned into a considerable foundation in transforming Indonesian women in terms of their relationship, marriage, and bearers of the future. In the context of marriageable age, it had never emerged as a political debate in public until Indonesian women gained access to Western/modern education during Dutch colonialism (Blackburn, 2002). In colonial Indonesia, debates and controversies against early marriage were a critical and political campaign for social reform campaigners, such as Dutch and Indonesian women, Javanese priyayi (civil servants), Indonesian secular nationalists, and Dutch colonial authorities. However, the support or preservation of early marriages during this period mostly came from local leaders, especially Muslims. On the other hand, women, who had obtained western education from Dutch schools, criticized Indonesian society's conditions, in relation to child marriage (Blackburn, 2002. At this stage, the definition of girlhood may follow the shift in value of what families consider as a standard of prestige. Recently, instead of arranging early marriage, parents prefer to send their daughters to school. They would even ask their daughters to focus more to their study rather than have a romantic relationship with boys (Hefner, 2005).

On the other hand, state ibuism (Suryakusuma, 1996) has successfully discovered that being a husband companion, a "manager mother", and a member of civil servants' wives organization a girl could be similar to the subject of a single woman. She lives within the family structure yet her position is not considered as an independent woman. In the construction of the patriarchal family, women are prohibited from becoming independent. They are defined through the power of their father, brother, or husband. The decision to give one's daughter away in marriage is to shift the responsibility of the father to the hand of her would be husband. Therefore, the ideology of state of ibuism has contributed to sustaining this structure by continuously propagating that the ideal concept of a woman is to become a wife or a mother or both (Suryakusuma, 1996). The study of state 
ibuism is mainly addressed to the phenomena of civil servants' wives in Indonesia. They are unified in a women organization called Dharma Wanita. The membership is mandatory and they socially learn about the important role of being a housewife as well as a perfect companion for their husband (Blackburn, 1997). As an attempt to strengthen this social construction in every level, the state also created the Family Welfare Guidance (Pembinaan Kesejahteraan Keluarga - PKK) program which is a housewives' organization among lower class society. Therefore, the hegemony of state ibuism works very efficiently to collectively control woman behaviors and ideas as it is not limited to middle-class society but it also spreads out throughout nearly all layers of society.

Being an independent woman would pose a serious problem in Indonesia. Single women are extremely prone to be stigmatized by society because their situation would be considered as a failure in creating a stable and established structure in the society. The society is afraid of losing the potential figure of wives and mothers because the public sphere cannot be fully created without the existence of the "domestic worker". This means that the family would also be unable to grow and develop if no one is available to reproduce and nurture the children.

In order to prevent such chaos, the social norms within the conception of maidenhood are created. Based on Bennett's research findings, the discussion on the values of the maiden is that they are primarily afforded to young women at menarche in which they are no longer considered as little girls. The new social identity of a maiden is constituted upon the dual assumptions of reproductive maturity and virginity. Concerning maturity, the identity is explicitly heterosexual in that it focuses on a woman's fecundity, her sexual vulnerability to the advances of men, and the assumption that maidenhood will end with marriage (Bennett, 2005). Marriage becomes the first keyword that constructs a border in which girls are compelled to follow a linear process; otherwise, they would be stigmatized as a deviant. The status of maiden is a contemporary term and it has to be stopped because there is no alternative destination except getting married. Failure to do so, will result in them being labeled as an "old-maid" which is perceived as a form of disgrace in Indonesia.

Meanwhile, in terms of virginity, Bennett (2005) commented on the relationship between maiden identity and the social reputation of Indonesian families. As virginity is always embedded to unmarried woman, it would be shameful if a girl were to engage in premarital sex or if she were pregnant outside of wedlock. One's virginity becomes a determinant for judging the moral standard of the girls and the family reputation. The discourse of virginity is even structured in the admission test requirement for becoming a policewoman. The moral panic, in relation to the virginity discourse, is increasingly greater when some schools conduct virginity testing for girls and it is considered as an important issue. In this sense, women's sexual behaviors are extremely vulnerable of being socially and publically condemned. Parents may, therefore, direct their daughters to control their behavior to avert further gossip, or they may publicly refute the accusations if they feel that the attack on their daughter and the family honor warrant such repudiation (Bennett, 2005). Likewise, the understanding of premarital sex and virginity is not only about the shame, but it is also about committing a sin and this may create social disintegration through their immoral transgressions (Parker \& Nilan 2013, p. 206 in Nilan 2016).

\section{The dimensions of teenage pregnancy}

As a global call, the ICPD (International Conference on Population and Development) document presents a strong recommendation to its member countries to strictly enforce laws concerning the minimum legal age of 
consent and the minimum age of marriage, and that member countries should raise the minimum age of marriage when it is deemed as necessary (ICPD 1994, para. 4.21). Further, this mandate urges member countries to increase awareness in providing more investment to girls' education and development. Twenty-five years after the ICPD, the global commitment ratified The Convention on the Rights of the Child, which is considered as more focused on the basic elements necessarry for the protection of girls and boys up to the time they reach adulthood (UNFPA, 2013). In this sense, children should be supported by proper facilities and should not be led into harmful traditional practices that would hinder their potential role in the development agenda. At a glance, both the ICPD and the CRC have carried out measures to abolish harmful customs such as child marriage and/or teenage pregnancy (UNFPA, 2013). It is assumed that teenage pregnancy is associated with pregnancy experienced by 16 to 19 -year-old girls because it remains to be a major contribution to maternal and child mortality, and to a never-ending cycle of ill-health and poverty (WHO, 2014). It is also reported that a number of adolescent pregnancies have lead to worse situations, such as early marriage, school dropout, or unsafe abortion. In other words, teenage pregnancy has unpleasant implications for the future, and it may prolong the cycle of poverty as it is transferred from teen parents to their children (Adam, Taylor, \& Pittman, 1989). However, I argue that changes of various constraints are seen to occur in Indonesia, the human rights standard employed in delivering the concept of global sex education is vulnerable in that it may subsequently allow another practice of normalization. This situation is actually related to Foucault's theory wherein power is regarded as an entity that scatters into social interactions; power itself contains such a productive aspect instead of merely being a repressive or hierarchal relation (Foucault, 1979).
At the regional level of the Association of South East Asia Nations (ASEAN), the discourses of teenage pregnancy or child marriage are not discussed. In ASEAN, the discussion generally refers to the commitment in enhancing social protection for women, children, and youths in relation to the issues of government resources (ASEAN Blueprint 2016, p. 16). Meanwhile, in Indonesia, the issue of teenage pregnancy has gained popularity following the government's involvement in a number of global commitments such as the ICPD, MDGs, and SDGs (Sadly, 2007). Holzner and Oetomo (2004) also noted that after the ICPD, the need for conducting sex education for teenagers was subsequently articulated. Numerous activities, especially in Java, where half of Indonesia's population live, were also developed. At the same time, several feminists had succeeded in bringing the human rights discourse in relation to sexuality and reproductive health and the needs of adolescent to the forefront of their activism. Adolescents were then increasingly required as a target group to ensure that education, family planning, and human rights can mutually function in creating the envisaged modern civilization.

Furthermore, education also has a strong influence in changing the perception and practices of marriage in Indonesia. Education leads people to define themselves in terms of their career aspirations as well as their roles within their family. Gavin Jones (2001) argues that education had succeeded in leading women to delay their early marriage. His analysis was very clear, showing that early marriage is closely related to poverty and education. In contrast, adult marriage refers to those who focus on their career, education, and well-planned future. This framing introduced the idea that marriage is no longer placed as a natural process; rather, it is utilized to identify the degree of progress.

Therefore, one of the approaches used by the UN to reduce the number of teenage pregnancy is through the implementation of sex education. It is undeniable that the standards 
of sex education are introduced with the intent of providing space for adolescent groups in dealing with issues of sexuality, reproductive health, and human rights. Instead of establishing adolescents as troublemakers, they are regarded as agents, sources of knowledge, and decision makers. However, sex education has not been well implemented in Indonesia as it confronts exceedingly diverse discourses related to the notion of sexuality itself. In the Indonesian marriage law, for instance, 15-year-old girls are allowed to marry, but concurrently there is a prohibition for students to become pregnant (age is unspecified). In other words, people want to follow the global standard discourse of teenage pregnancy on the one hand, but they also indicate reluctance to revise the law on the basis of religious reasons on the other. Nonetheless, it may also be considered as nonsensical to expel pregnant students, in cases where they are pregnant within marriage.

In relation to more practical issues, some teachers would subsequently conduct sex education by stressing the dangers of premarital sex for teenage students.

"I strongly suggest that my students stay strictly away from premarital sex acts because it is a moral violation. Concerning puberty and pious acts during the baligh period, I also agree that female students may be more vulnerable since there is the risk of pregnancy" (YL, a guidance counselor at a public school).

The above argument may be true due to the fact that premarital sex is one of the main driving factors of teenage pregnancy, which is an unwanted condition. Moreover, the notion of unwanted here is very much in line with the school's rule of expelling pregnant students. Since schools do not accept their pupils to become pregnant while they are students, they should consequently be expelled from school.

"Based on past experiences, this school had cases of pregnant students which, in fact, resulted in a difficult dilemma. On the one hand, the school needed to maintain its reputation that has always been based on the society's demand, in terms of moral virtue. However, it was also not easy to let the girls' future be at risk" (TY, a guidance counselor at a private school).

Therefore, the discourse of teenage pregnancy is not only limited to discussions of human rights or poverty reduction, rather it also relates to the ambiguity in finding a proper place for the girls itself. It may actually be a paradox; On the one hand, there are massive initiations of the global call to empower girls to become independent beings. Yet, on the other hand, the discourse of teenage pregnancy, in institutions such as schools, is mobilized to determine the standard of being an educated young individual in today's society.

\section{The Rule of Expelling Pregnant School Girls}

It is an intriguing point when schools, instead of consistently applying rules of human rights relating to education, prefer to suspect married and then pregnant students as moral offenders. In some schools, teachers even carry out an inspection prior to students taking their final exam, which results in a skyrocketing number of girls being expelled from schools toward the end of semester. Schools likely applies double standards here: Schools emerge as the agent of modernity, yet concurrently serve as the keeper of morality. A girl named NA gave her testimony regarding her experience of being pregnant as a school girl:

"It was really scary to be pregnant and a student at the same time. At that time, the guidance counselor summoned me and asked whether I was pregnant. I was really frustrated because based on my friend's experience, she was asked to resign from school and stop attending school. The counselor 
forced me to confess that I was pregnant by asserting the rule that pregnant students are prohibited from attending this school and that they must be expelled". (testimony of NA, a girl who experienced teenage pregnancy).

Several SMA Negeri (public high schools) in Yogyakarta nowadays even have written rules stating that both the pregnant school girl and the school boy involved will be given demerit points of 101. Students who have obtained more than 100 demerit points would consequently have to resign or be expelled from the school. However, it is, in fact, more difficult to identify male students who had gotten the girls pregnant than pregnant school girls.

Kalyanamitra (2013), through their content analysis research, found that some schools in eight areas had expelled pregnant students prior to the national exam. The schools mostly said that those pregnant girls were not allowed to participate in the national exam because they, by being pregnant, had violated the school rules. In a specific case in Batam (a municipality in the Riau Islands Province) some schools even gave pregnant students lower grades than criminally charged or drug-addict students. Also, in Mojokerto (a regency in East Java), the head of the regional education office stated that there is no possibility for pregnant students to join the final exam. In his opinion, this rule does not have any correlation to issues of human rights, it should, instead, be understood that the purpose of education is to guide students toward the most ideal path. He assumes that being pregnant during their school term indicates a disciplinary violation and it is morally unacceptable. In addition, the rule is not only applied during the national exam, the school would also take strict actions that included expelling pregnant students in the middle of the school term (Kristyarini, 2014).

In the context of equal education for girls, especially in Indonesia, it may be considered sensible when recent sociological approaches attempt to place education as part of human capital (Bourdieu in Swartz, 1997). In this sense, the idea to encourage girls to become a promising future generation and leaders through education would be well equipped. However, when we assume education as one of the products of modernity, we should be aware of the assumption that women are in most cases more alienated than men because she is closer to nature (Felsky, 1995). Nature here refers to nurturing activities or it simply relates to the materiality of life, which is very body-oriented.

There is a girl, DS, who got pregnant six months before the final exam. At first, DS did not tell anyone except her boyfriend about her pregnancy. She was afraid that her parents would be angry and the worst case was that she would have a problem with her school. Her boyfriend then initiated to carry out an abortion by asking DS to drink jamu (herbal medicine). Although DS had drank jamu several times, she could not end her pregnancy. She finally could not hide her pregnancy symptoms from her family, friends, and teachers. The point is that DS and her boyfriend immediately knew that the pregnant body should be removed, otherwise DS would lose all recognitions as both a good daughter and student.

Similar type of measures were also seen to happen among the parents. One of the pregnant girl's parents came up with the idea of sending their daughter away to a shelter. One of the girls who just delivered her baby in the shelter testified:

"I do not intend to come back to school. I am already tired of following the school routines after being like this [read: being pregnant, resigning from school, and having a baby]. I will just get a hair salon training here and then work."

According to this study, it can be argued that the discourse of teenage pregnancy has indicated that there is a place for pregnant 
school girls in modern society as long as they do not mind living apart from their as long as they do not mind casting aside their maternal roles, which are considered to be old-fashioned practices.. In addition, it is very important to internalize the fantasy of being a modern girl who will always be present in the public sphere, yet she must voluntarily keep away from her traditional femininity. To be girl in a modern society means to be a student who strictly follows the rules of the school; otherwise, she cannot find her place in public.

\section{Conclusion}

Concerning the issue of pregnant school girls, it may be problematic to adopt the discourse of teenage pregnancy, especially in Indonesia, in a binary categorization such as between being modern and not-modern. In addition to being prone in creating a hierarchy, the dichotomy also positions the girls in a state of ambiguity. On the one hand, the girls are encouraged to play a role in modern society, yet the pregnant student prohibition rule has, in fact, reproduced the discourse that modernity is closely associated with public or male zones, and this means that all things related to femininity would be rejected to exist. This is a paradox or the teenage pregnancy discourse also tends to be prejudicial to pregnant school girls.

The construction process of becoming modern and progressivemay involve features flowing from unknown directions. However, since Indonesia actively joins a number of global agreements on human rights, the dilemma to manage the issue of teenage pregnancy may be uncertain. On the one hand, the label as a third world country has implied several burdens in which the achievements of first world countries would be a reference. In fact, the division of the First and the Third World often places the Third World women as victims, dependent, and colonialized (Grewal \& Kaplan, 1994). Here, the general objective in constructing the discourse of teenage pregnancy is highly related to the fantasy of "becoming more developed" in which it is addressed to the developing countries. However, in Indonesia, through the minimum age standard of marriage, there is no dynamics within the imagination of being modern. People take these global ideas for granted instead, and they find the routines within values of religions, social norms, and customs. Accordingly, the place for these pregnant school girls in modern society or in public is considerably blurred.

An important point that can be taken from this research is that it is necessary to critically question the meaning of the teenage pregnancy discourse, in terms of sexuality and body discipline. I argue that the idea to revise the minimum age standard, as an attempt to establish modernization, is likely not the main point, and expulsion of pregnant students from schools is also not the best solution due to the will to sterilize the public space from the nature of femininity. The method used to link the discourse of teenage pregnancy with issues of human rights, equality, and poverty may be acceptable. However, it cannot be simplified by overgeneralizing the matter due to the abstract imagination of the societal space in the global framework.

\section{References}

Adam, G., Taylor, S. A., \& Pittman, K. (1989). Adolescent pregnancy and parenthood: A review of the problem, solution, and resources. Family Relation, 38(2), 223-229. doi: 10.2307/583680

Bartky, S. L. (1990). Foucault, femininity and the modernization of patriarchal power. In S. L. Bartky (Eds.), Femininity and domination (pp. 63-82). United Kingdom: Routledge.

Bennett, L. (2005). Women, islam and modernity: single women, sexuality and reproductive health in contemporary Indonesia. London and $\mathrm{New}$ York: Routledge.

Blackburn, S. (2002). Women and the state in modern Indonesia. New York: Cambriedge University Press 
Caldas, S. J. (1993). Current theoretical perspectives on adolescent pregnancy and childbearing in United States. Journal of Adolescent Research, 8, 4-20.

Dillon, M. E., \& Cherry, A. (2014). An international perspective on adolescent pregnancy. In A. L. Cherry \& M. E. Dilon (Eds.), International handbook of adolescent pregnancy: medical, psychosocial, and public health responces (pp. 1-38). New York: Springer.

Felsky. R. (1995). The Gender Of Modernity. Cambridge: Harvard University Press.

Foucault, M. (1979). The History Of Sexuality. Paris: Editions Gallimard.

Foucault, M. (1979). Discipline And Punish: The Birth Of Prison. New York: Random House.

Geertz, H. (1961). The Javanese Family: A Study Of Kinship And Socialization. Glencoe: II: Free Press.

Grewal, I., Inderpal \& Kaplan. C., (1994). Introduction: Transnational feminist practice and question of postmodernity. In I. Grewal \& C. Kaplan (Eds.), Scattered hegemonies: postmodernity and transnational feminist practices (pp. 1-33). Minneapolis: University of Minnesota Press.

Handajani, S. (2008). Western inscription on Indonesia bodies: Representations of adolescents in Indonesian female teen magazines. Intersection: Gender and Sexuality in Asia and The Pacific, 18.

Holzner, B. M., \& Oetomo, D. (2004). Youth, sexuality and sex education messages in Indonesia: Issues of desire and control. Reproductive Health Matters, 12(23), 40-49.

Hughes, N. S., \& Lock, M. M. (1987). The mindful body: A prolegomenon to future work in medical anthropology. Medical Anthropology Quarterly, 1(1), 6-41.

Itriya, F., \& Asriani, D. (2014). Agensi dan negoisasi remaja hamil dalam menghadapi stigma dan Hambatan- hambatan dalam kehidupannya di Kota Yogyakarta (Agency and pregnancy girl negotiation in facing the stigma and obstacles in Yogyakarta) (Rep.).
Jones, W. G. (2001). Which Indonesian women marry youngest, and why? Journal of Southeast Asian Studies, 32(1), 67-68.

Kalyanamitra. (2003). Analisis media: ujian nasional yang merampas hak konstitusional [Media analysis: national exam violating constitutional rights]. Jakarta Timur: Kalyanamitra.

Kelly, D. M. (1996). Stigma stories: four discourse about teen mothers, welfare, and poverty. Youth \& Society, 27, 421-449.

Kim, E. (2009). [On this topic] The politics of the body in contemporary Korea. Korea Journal, 49(3), 5-14.

Kim, J. (2014). Silent cry: Adolescent pregnancy in South Korea. In A. L. Cherry \& M. E. Dilon (Eds.), International handbook of adolescent pregnancy: medical, psychosocial, and public health responces (pp. 563-574). New York: Springer.

Kristyarini. (2014, February 10). Siswa Hamil Dilarang Ikut Ujian Nasional [Pregnant Students are not Allowed to Attend National Exam]. Kompas-Online. Retrieved from http://regional.kompas.com/

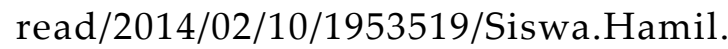
Dilarang.Ikut.Ujian.Nasional.

Nagel, J. (1998). Masculinity and nationalism: gender and sexuality in the making of nations. Etnic and racial studies, 21. Routledge.

Nilan, P. (2016). Local Modernities: Young Women Socializing Together. Leiden.: KITLV.

Parker, L., \& Nilan, P. (2013). Adolescent in contemporary Indonesia. London \& New York: Routledge.

Parker, L. (2009). Religion, class and schooled sexuality among Minangkabau teenage girls. Bijdragen tot de taal-land-en volkenkunde, 165(1), 62-94.

Ringrose, J., \& Renold. E. (2016). Mapping girls' affective encounters with femininity, sexuality, and feminism at school. In C. Mitchell \& C. Rentscher (Eds.), Girldhood and the politic of place. New York: Berghan. Sarlito, S. (2011). Psikologi Remaja [The 
Psychology of Adolescent]. Jakarta: Rajawali Pers.

Swartz, D. (1997). Culture And Power: The Sociology Of Pierre Bourdieu. Chicago: The University of Chicago Press.

Sem, U. Y. (2005). Bodies in places, places in bodies. In W. Harcourt, A. Escobar (Eds.), Women and the politics of place. Bloomfield: Kumarian Press.

Sadly, S. (2007). Meningkatkan kesehatan masyarakat melalui perubahan undangundang kesehatan [Increasing the Society Health by revising the law of health]. Journal of Feminist, 23-38.

Soeprayitno. (2015, February 5). Tes keperjakaan dan keperawanan bebani mental siswa (Virginity test makes burden for students). Sindonews. Retrieved from http://daerah. sind onews.com/read/960178/23/teskeperawanan-keperjakaan-bebani-mentalsiswa-1423058304

Suryakusuma, J. (1996). The state and sexuality in new Order Indonesia. In L. J. Sears (Eds.),
Fantaszing the Feminine in Indonesia. United States: Duke University Press.

Suryakusuma, J. (2016, October 19). Sex, lies and tapegate: Raising awareness for women's rights?". The Jakarta Post. Retrieved from http://www.thejakartapost.com/ news/2016/10/19/sex-lies-and-tapegateraising-awareness-women-s-rights.html

UNESCO \& UNFPA. (2013). Youth and comprehensive sexuality education. Retrieved from http://www.un.org/esa/ socdev/documents/youth/fact-sheets/ youth-sexuality-education.pdf

UNFondation. (2015). Briefing Cards: Sexual and reproductive health and rights (SRHR) and post2015 development agenda. Retrieved from http://www.unfoundation.org/what-wedo/campaigns-and-initiatives/universalaccess-project/briefing-cards-srhr.pdf

UNFPA. (2016). Comprehensive sexuality education. Retrieved from http://www.unfpa. org/comprehensive-sexuality-education 